\title{
Correction to: Livelihood diversification as key to long-term non-migration: evidence from coastal Bangladesh
}

\author{
Bangkim Biswas $^{1} \cdot$ Bishawjit Mallick $^{2,3}$ (D)
}

Published online: 20 July 2021

(c) The Author(s) 2021

\section{Correction to: Environment, Development and Sustainability (2021) 23:8924-8948 https://doi.org/10.1007/s10668-020-01005-4}

The article "Livelihood diversification as key to long-term non-migration: evidence from coastal Bangladesh" written by Bangkim Biswas and Bishawjit Mallick was originally published electronically on the publisher's internet portal on 3 October 2020 without open access. The article is funded under Open Access funding enabled and organized by Projekt DEAL.

The article is forthwith distributed under a Creative Commons Attribution 4.0 International License, which permits use, sharing, adaptation, distribution and reproduction in any medium or format, as long as you give appropriate credit to the original author(s) and the source, provide a link to the Creative Commons licence and indicate if changes were made. The images or other third party material in this article are included in the article's Creative Commons licence, unless indicated otherwise in a credit line to the material. If material is not included in the article's Creative Commons licence and your intended use is not permitted by statutory regulation or exceeds the permitted use, you will need to obtain permission directly from the copyright holder. To view a copy of this licence, visit http://creativeco mmons.org/licenses/by/4.0. The funding note has been added in the original publication.

The original article can be found online at https://doi.org/10.1007/s10668-020-01005-4.

Bangkim Biswas

Bishawjit.Mallick@tu-dresden.de; Bishawjit.Mallick@colorado.edu;

Bishawjit.Mallick@googlemail.com

Bishawjit Mallick

bangkimbiswas@gmail.com

1 Economics Discipline, Khulna University, Khulna 8208, Bangladesh

2 Chair of Environmental Development and Risk Management, Technische Universität Dresden (TUD), Dresden, Germany

3 CU Population Center Institute of Behavioral Science, University of Colorado Boulder Campus, Boulder, CO 80309, USA 
Open Access This article is licensed under a Creative Commons Attribution 4.0 International License, which permits use, sharing, adaptation, distribution and reproduction in any medium or format, as long as you give appropriate credit to the original author(s) and the source, provide a link to the Creative Commons licence, and indicate if changes were made. The images or other third party material in this article are included in the article's Creative Commons licence, unless indicated otherwise in a credit line to the material. If material is not included in the article's Creative Commons licence and your intended use is not permitted by statutory regulation or exceeds the permitted use, you will need to obtain permission directly from the copyright holder. To view a copy of this licence, visit http://creativecommons.org/licenses/by/4.0/.

Publisher's Note Springer Nature remains neutral with regard to jurisdictional claims in published maps and institutional affiliations. 